\title{
FISH DIVERSITY OF GHODAGHODI LAKE \\ IN KAILALI, FAR-WEST NEPAL
}

Dipendra Joshi and Bijaya K. C.

Journal of Institute of Science and Technology

Volume 22, Issue 1, July 2017

ISSN: 2469-9062 (print), 2467-9240 (e)

\section{Editors:}

Prof. Dr. Kumar Sapkota

Prof. Dr. Armila Rajbhandari

Assoc. Prof. Dr. Gopi Chandra Kaphle

JIST, 22 (1): 120-126 (2017)

\section{Published by:}

Institute of Science and Technology

Tribhuvan University

Kirtipur, Kathmandu, Nepal 


\title{
FISH DIVERSITY OF GHODAGHODI LAKE IN KAILALI, FAR-WEST NEPAL
}

\author{
Dipendra Joshi" and Bijaya K. C. \\ Central Department of Zoology, Tribhuvan University, Kirtipur, Nepal \\ *Corresponding E-mail: dipendra.joshi70@hotmail.com
}

\begin{abstract}
Ghodaghodi Lake is an ox-bow perennial lake of Ghodaghodi Lake Complex, situated in Kailali district. The present study was conducted to understand the fish diversity, community structure and distribution pattern in Ghodaghodi Lake. A total of 13 fish species were recorded from the different section of Ghodaghodi Lake, belonging to five order, eight family and eleven genera. According to fish catch the dominant order and family of Ghodaghodi Lake were found to be Cypriniformes (40\%) and Cyprinidae (40\%) respectively. The dominant fish species of Ghodaghodi Lake was Labeo gonius followed by Mystus tengara, Nandus nandus and Channa striatus. The highest diversity index (2.46), species richness (6.14) and evenness (0.96) of fish were recorded from station III during the month of January. Lowest diversity index (1.75) and evenness (0.90) was found in station II and during the month of October (2.25 and 0.88). Similarly, lowest species richness was found in station I (3.91) and during the month of July (5.82). Fish diversity and number in Ghodaghodi Lake were found to have decreased. This could be due to pollution, illegal fishing and excessive proliferation of aquatic weeds.
\end{abstract}

Keywords: Fish diversity, Labeo gonius, Community structure, Cyprinidae, Species of turtle.

\section{INTRODUCTION}

Ghodaghodi Lake complex is the largest interconnected natural lake system, situated in Kailali District of Far-Western Development Region of Nepal, at an altitude of $205 \mathrm{~m}$. It lies between $28^{\circ} 41^{\prime} 03^{\prime \prime} \mathrm{N}, 80^{\circ} 56^{\prime} 43^{\prime \prime} \mathrm{E}$ (DNPWC, 2005). It is positioned in a very strategic location between Bardia National Park and Suklaphanta Wildlife Reserve and alongside the east- west highway. Ghodaghodi Lake complex includes about 13 associated lakes and ponds and covers an area of 2563 hectares (Anon 2002), with associated marshes, swamps, streams, springs, seasonal marshy grasslands, and artificial wetlands (canals, irrigated fields, ponds, etc.) surrounded by tropical deciduous mixed forest in the lower slopes of Siwalik hills. The lake complex encompasses three Village Development Committees (VDCs) of Kailali district namely Darakh, Sandepani and Ramshikharjhala. The area is bordered by Sandepani VDC in the east and north, Ram Shikar Jhala VDC in the west and Mahendra Highway in the south. It was designated as Ramsar Site on 13 August 2003. The area is remarkable for its rich biodiversity and connectivity between the Terai plains and the Siwalik of Nepal (Kafle, 2006). It provides habitat for 34 species of mammals, around 29 species of fish including threatened and endemic species, around 140 species of birds (migratory \& resident) representing 16\% of the national avifauna and 9 species of herpeto fauna including three species of turtle (DNPWC and WWF Nepal, 2003). Major lakes of the complex include Ghodaghodi (138 ha), Nakharodi (70 ha), and Baishawa (10 ha). Out of 13 lakes Ghodaghodi and Nakharodi are only perennial lakes while others are seasonal.

Ghodaghodi Lake (138 ha) is the largest ox-bow lake of Nepal with $28^{\circ} 41.06^{\prime}$ latitude and $80^{\circ} 56.44^{\prime}$ longitude and have topography roughly palm shaped with many ramifications. Hydrology of lake is fed by atmospheric inputs, surface flows, springs. It has no inlet with two outlets along the Mahendra high way. It has sub tropical monsoonal type of climate with dry winter and rainy summer. Ghodaghodi Lake has not yet been largely investigated and its biodiversity is still unknown by the scientific world. Little is known on fishes from Ghodaghodi Lake. Therefore there is a need to investigate fish diversity in this lake and eventual threats for their survival. The main aim of the study was to explore the fish diversity of Ghodaghodi lake. 


\section{MATERALS AND METHODS}

\section{Study Area}

The present study was carried out in the Ghodaghodi Lake. It is one of the largest and most diverse perennial ox-bow lake of Ghodaghodi lake complex. It is protected area and prohibited for

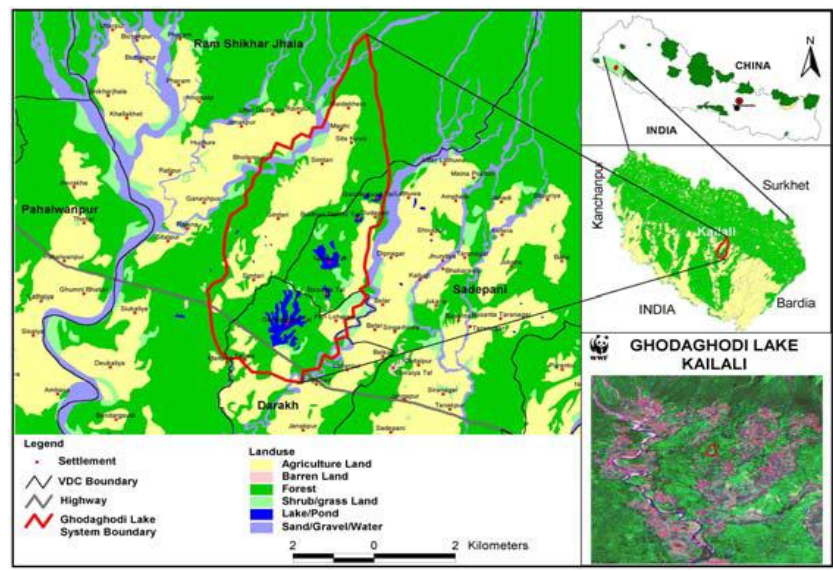

fishing and other activities in the lake. The lake does not contain inlet but has two outlets near the Mahendra highway. The lake is surrounded by dense forest in three sides and one side is near the Mahendra Highway.

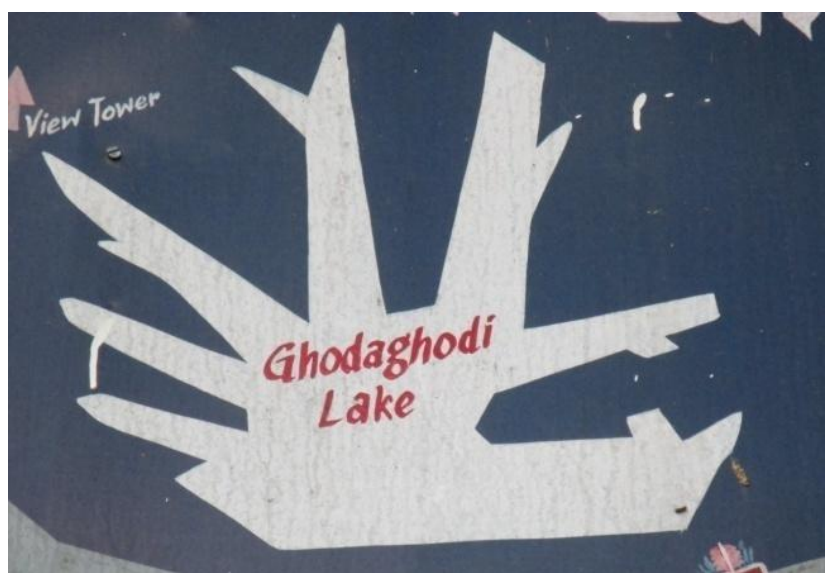

Fig. 1. Study area.

\section{Collection and identification of fishes}

The fishes were collected from each sampling sites by employing local fisherman to find out the systematic position, average abundance and distribution pattern. The habitat conditions like spawning ground and shelter and characteristic features of lake were observed during the field trips. Fishes were collected by using locally prepared fishing gear like cast net, hook line etc. The measurement and photography was taken in the field of all the collected fishes. The collected specimens were fixed in 10 percent formalin and preserved in 5\% formalin. The preserved
Specimens were brought to the laboratory of Central Department of Zoology (CDZ) for identification. These collected fish samples were identified using standard literatures of fish taxonomy after Shrivastava (1968), Day (1878), Shrestha (1981), Jayram (1981), Talwar \& Jhingran (1991), Shrestha (2001) and Shrestha (2008).

\section{Statistical Analysis}

The relation of fish with temperature, depth, transparency, turbidity, conductivity of water, $\mathrm{pH}$, $\mathrm{DO}$, free $\mathrm{CO}_{2}$, and hardness of water was calculated by using correlation coefficient formula given by Karl Person (Gupta, 1988).

$$
\text { Correlation Coefficient }(\mathrm{r})=\frac{N \cdot \varepsilon x y-\varepsilon x \varepsilon y}{\sqrt{N \cdot \varepsilon x^{2}-(\varepsilon x)^{2}} \sqrt{N \cdot \varepsilon y^{2}-(\varepsilon y)^{2}}}
$$

\section{Diversity Status}

\section{Species Diversity Index}

The diversity of species was calculated by using Shannon-Weiner diversity index (Shannon and Weaver, 1949).

Shannon-Weiner diversity index is designated as $\mathrm{H}^{\prime}$, which is calculated as:

$$
\mathrm{H}^{\prime}=-\Sigma(\mathrm{Pi}) * \ln (\mathrm{Pi})
$$

Where,

$$
\begin{aligned}
& \mathrm{Pi}=\mathrm{ni} / \mathrm{N} \\
& n i=\text { Number of individuals of species } \mathrm{i} .
\end{aligned}
$$

$$
\begin{aligned}
& \mathrm{N}=\begin{array}{l}
\text { Total number of all individuals in the } \\
\text { sample. }
\end{array} \\
& \ln =\text { Logarithm of base (e). }
\end{aligned}
$$

\section{Species richness index $(d)$}

The species richness was calculated by using Margalef Species richness (Margalef's, 1958). Margalef richness index is designated as d, which is calculated as:

$$
\text { Margalef species richness }(\mathrm{d})=\mathrm{S}-1 / \log \mathrm{N}
$$

Where, 


$$
\begin{aligned}
& \mathrm{S}=\text { Total number of species } \\
& \mathrm{N}=\text { Total number of individuals in the } \\
& \text { sample }
\end{aligned}
$$

\section{Evenness index}

To calculate whether species are distributed evenly across seasons and across landscapes elements, evenness index was determined by the following equation (Pieleu, 1966).

Where,

$$
\mathrm{E}=\mathrm{H}^{\prime} / \log \mathrm{S}
$$

$\mathrm{H}^{\prime}=$ Shannon-Wiener's diversity index.

$\mathrm{S}=$ Total number of species in the sample.

\section{RESULTS}

\section{Fish diversity in Ghodaghodi Lake}

The Ghodaghodi Lake provides a habitat for diverse type of freshwater fishes. Thirteen different fish species were reported during the present study, which includes five orders, eight families and eleven genera. According to the present study highest diversity was found in station III and lowest in station II. The dominant fish species of Ghodaghodi Lake are Labeo gonius, Mystus tengara, Nandus nandus followed by Channa striatus, Channa punctatus etc (Table 1). Table 1

\begin{tabular}{|c|c|c|c|c|}
\hline S.N. & Order & Family & Scientific name of fish & Local name \\
\hline \multirow{5}{*}{1} & \multirow{5}{*}{ Cypriniformes } & \multirow{5}{*}{ Cyprinidae } & Labeo gonius & Karsa \\
\hline & & & Puntius sophore & Sidhra \\
\hline & & & Amblyphryngodon microlepis & Mada \\
\hline & & & Amblyphryngodon mola & Mada \\
\hline & & & Esomus danricus & Dedhawa \\
\hline 2 & Siluriformes & Bagridae & Mystus tengara & Tenger \\
\hline 3 & Beloniformes & Belonidae & Xenentodon cancila & Kauwa \\
\hline 4 & Synbranchiformes & Mastacembelidae & Macrognathus pancalus & Bami \\
\hline \multirow{5}{*}{5} & \multirow{5}{*}{ Perciformes } & Ambassidae & Pseudambassis baculis & Chanari \\
\hline & & \multirow{2}{*}{ Nandidae } & Nandus nandus & Dhoke \\
\hline & & & Badis badis & Pasari \\
\hline & & \multirow{2}{*}{ Channidae } & Channa punctatus & Helae \\
\hline & & & Channa striatus & Helae \\
\hline
\end{tabular}
explains the species diversity of fish in Ghodaghodi Lake and their local name abundance.

Table 1. Fish species occurrence and diversity in Ghodaghodi Lake.

\section{Statistical analysis of ichthyofauna with different variables}

The correlation between different physiochemical variables and fish diversity of different station was analyzed by Karl Pearson's correlation coefficient method. The correlation between temperature and fish diversity was found to be positively correlated $(0.1755,0.5374,0.9771$ and 0.5652$)$ in all four station. Station III showed the high degree positive correlations while the station I showed low degree positive correlation. Similarly, fish diversity and water depth were positively correlated in station I (0.2476), II (0.4376) and IV (0.7597) while station III showed negative correlation (-0.2011). Transparency and fish diversity showed positive correlation in station I (0.9724), III (0.3509) and IV (0.6779) but it was negative in station II (-0.4025). Similarly station I, II and IV showed the positive correlation $(0.442,0.6486$ and 0.823$)$ between turbidity and fish diversity while in station III $(-0.2971)$ it showed negative correlation.

Fish diversity and conductivity were negatively correlated in station I (-0.1034), II (-0.5913) and IV $(-0.786)$ while it was positively correlated in station III (0.6257). Similarly, positive correlation was observed between $\mathrm{pH}$ value and fish diversity (0.7701, 0.8256, 0.5767 and 0.7337). All four stations showed positive correlation (0.8242, $0.8074,0.9345$ and 0.6508$)$ between dissolved oxygen and fish diversity (Table 2). 
Table 2. Correlation coefficient between water quality parameters and fish diversity.

\begin{tabular}{|l|l|l|l|l|l|l|l|l|l|}
\hline \multirow{2}{*}{ S.N. } & \multirow{2}{*}{ Variables } & \multicolumn{2}{|c|}{ Station I } & \multicolumn{2}{c|}{ Station II } & \multicolumn{2}{c|}{ Station III } & \multicolumn{2}{|c|}{ Station IV } \\
\cline { 2 - 10 } 1 & $\mathbf{R}$ & $\mathbf{P E}(\mathbf{r})$ & $\mathbf{r}$ & $\mathbf{P E}(\mathbf{r})$ & $\mathbf{R}$ & $\mathbf{P E}(\mathbf{r})$ & $\mathbf{r}$ & PE (r) \\
\hline & $\begin{array}{l}\text { Temperature } \\
\text { and Fish } \\
\text { Diversity }\end{array}$ & 0.1755 & 0.1813 & 0.5374 & 0.1331 & 0.9771 & 0.0153 & 0.5652 & 0.1273 \\
\hline 2 & $\begin{array}{l}\text { Water Depth } \\
\text { and Fish } \\
\text { Diversity }\end{array}$ & 0.2476 & 0.3165 & 0.4376 & 0.2726 & -0.2011 & 0.32361 & 0.7597 & 0.1425 \\
\hline 3 & $\begin{array}{l}\text { Transparency } \\
\text { and Fish } \\
\text { Diversity }\end{array}$ & 0.9724 & 0.0183 & -0.4025 & 0.2825 & 0.3509 & 0.2957 & 0.6779 & 0.1822 \\
\hline 4 & $\begin{array}{l}\text { Turbidity and } \\
\text { Fish Diversity }\end{array}$ & 0.442 & 0.1505 & 0.6486 & 0.1953 & -0.2971 & 0.3074 & 0.823 & 0.1088 \\
\hline 5 & $\begin{array}{l}\text { Conductivity } \\
\text { and Fish } \\
\text { Diversity }\end{array}$ & -0.1034 & 0.3336 & -0.5913 & 0.2193 & 0.6257 & 0.2051 & -0.786 & 0.1288 \\
\hline 6 & $\begin{array}{l}\text { PH Value and } \\
\text { Fish Diversity }\end{array}$ & 0.7701 & 0.1372 & 0.8256 & 0.10734 & 0.5767 & 0.225 & 0.7337 & 0.1556 \\
\hline 7 & $\begin{array}{l}\text { DO and Fish } \\
\text { Diversity }\end{array}$ & 0.8242 & 0.1081 & 0.8074 & 0.1173 & 0.9345 & 0.0427 & 0.65082 & 0.1943 \\
\hline 8 & $\begin{array}{l}\text { Free CO2 and } \\
\text { Fish Diversity }\end{array}$ & -0.6628 & 0.189 & -0.723 & 0.1609 & 0.769 & 0.1378 & 0.3988 & 0.2835 \\
\hline $\begin{array}{l}\text { Fardness and } \\
\text { Fish Diversity }\end{array}$ & -0.889 & 0.0706 & -0.8098 & 0.116 & 0.2148 & 0.3216 & -0.3512 & 0.2956 \\
\hline
\end{tabular}

\section{Diversity status of fish fauna of Ghodaghodi Lake}

The value of Shannon-Wiener diversity index $\left(\mathrm{H}^{\prime}\right)$, Evenness (E) and Margaleaf richness (d) were calculated according to month and stations. Highest Shannon-Wiener diversity index (2.46) was found in station III and the lowest (1.75) was found in station II. Similarly, highest Shannon Wiener diversity index value (2.42) was found in January, where as lowest (2.25), was found during October. No significant difference was found in the mean Shannon-Wiener diversity index among the stations and months. The maximum Margalef richness value was observed
6.14 at station III, where as minimum value was found to be 3.91 at station I. Similarly, highest Margalef richness value was found to be 6.32 during January, where as lowest value was found to be 5.82 during July. Evenness index was found to be highest (0.96) at station III, and the lowest value (0.90) was found in station II. Similarly, highest evenness value was found to be 0.95 in January and lowest value was found to be 0.88 in October. No significant difference was found in evenness value among the months and stations. The value of Shannon Weiner diversity, Margalef richness and the evenness in different stations and in different months are presented as- 


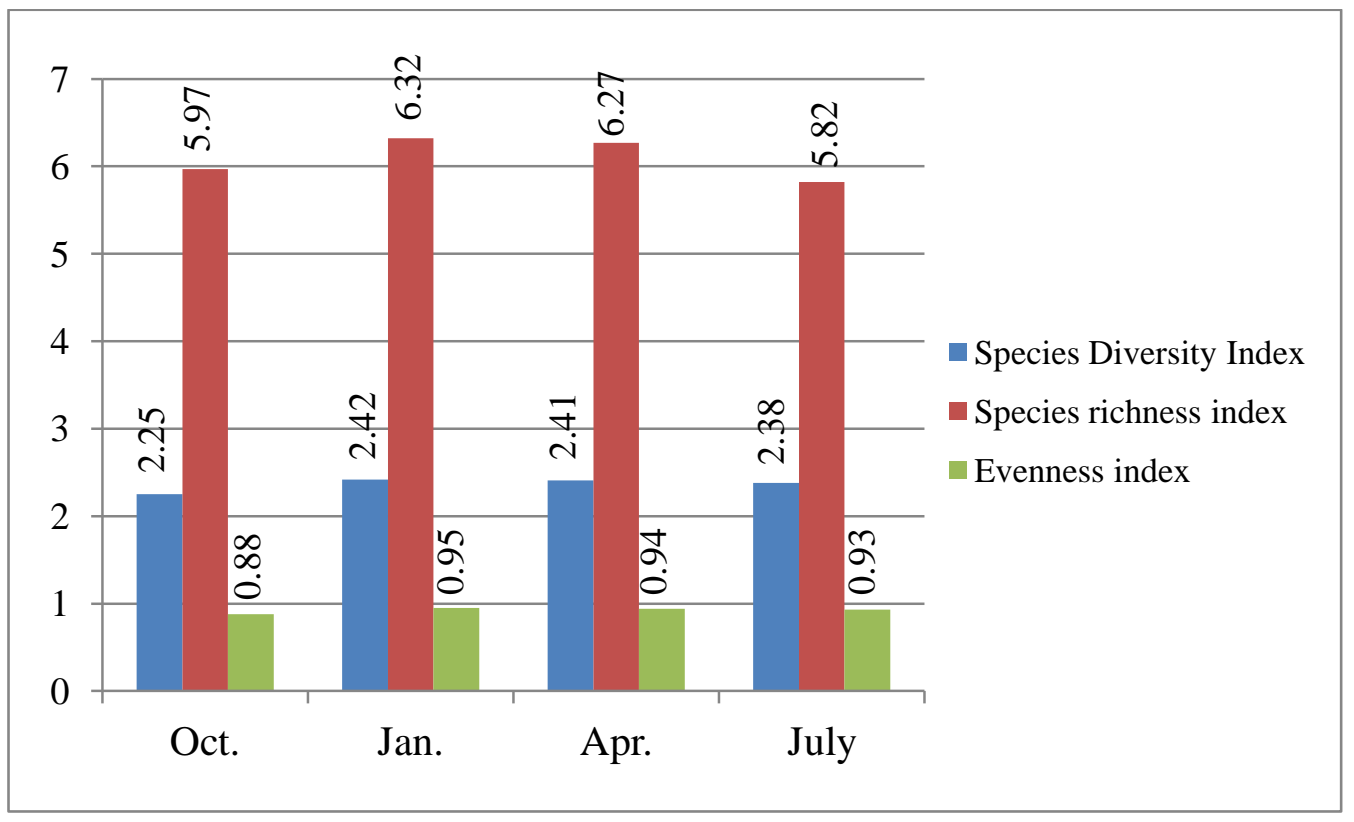

Fig. 2. Month wise diversity index, species richness index and evenness index.

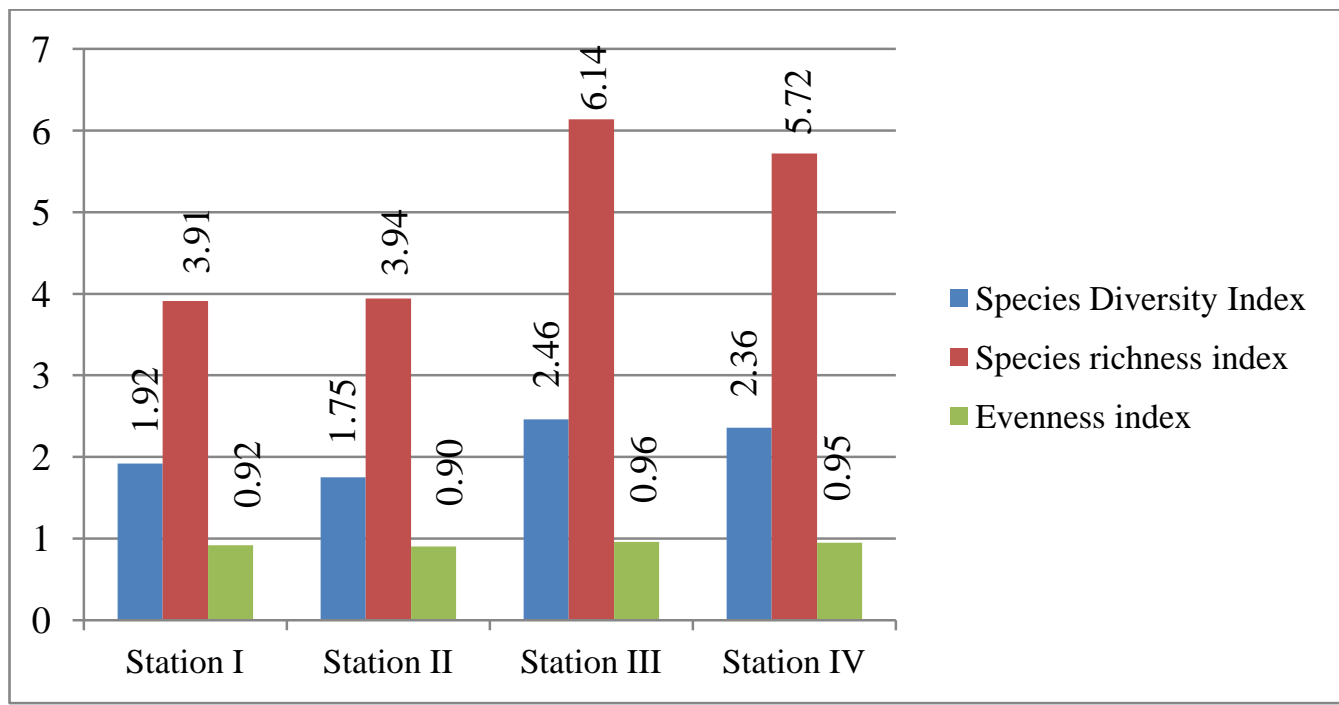

Fig. 3. Station wise diversity index, species richness index and evenness index.

\section{DISCUSSION}

The present study was conducted for a period of 10 months, from October 2014 to July 2015 to cover four different seasons. A total of 13 species of fish fauna were collected from different sampling station of Ghodaghodi Lake which belongs to five orders, eight families and 11 genera. IUCN (1998) identified 27 species of fish fauna from Ghodaghodi Lake Complex. DNPWC and WWF Nepal (2003) reported 29 fish species from Ghodaghodi Lake Complex. Kafle (2007) identified 25 species from same area. Recently Lamsal et al.
(2014) recorded 9 fish species from Ghodaghodi Lake complex. Among them Clarias batrachus, Channa striatus, Puntius sophore, Mastacembelus pancalus, Xanentodon cancila are common fish species in all studies. Some species such as Labeo boga, Mystus vitatus, Colisa fasciatus etc were not found in present study. Ghodaghodi Lake, the dominant orders were Cypriniformes and Perciformes. Out of total fish species $78 \%$ belonged to these two orders. Similarly highest fish catch was from order Cypriniformes (40\%), so the most dominant species was from order Cypriniformes. 
Pokharel (1999) has reported Cypriniformes as the most dominant order holding maximum number of species and contributing maximum catch in percentage in the lakes of Pokhara valley. Edds (1986) also reported the order Cypriniformes was common order of Kaligandaki and Narayani Rivers. Sharma and Shrestha (2001) and Shrestha (2003) also reported order Cypriniformes constituting highest catch in the Tinau River and Dano River respectively. Majority of the fish species collected from the River fall under the order Cypriniformes, this is the largest order of fresh water fishes, which includes 2,422 species (Nelson, 1984).

Similarly Labeo gonius was the most dominant species in the Ghodaghodi Lake. This species was recorded throughout the year. The frequency occurrence of this species was $17 \%$ compared to Macrognathus pancalus, which was only $2 \%$. Gautam et al. (2016) reported 23 fish species including 19 indigenous and 4 exotic species from Lake Rupa. But no exotic species were reported from Ghodaghodi Lake. Similarly, many local people were illegally fishing in those areas which are difficult to the reach of the government people. This could lead to the decrease in fish population.

The Shannon-Weaver biodiversity index values obtained from present study was not very high. The reason for showing lower species biodiversity is that fishing gears used have high selectivity effect (Keskin \& Unsal 1998). Highest Shannon diversity index was found in station III (2.46) and during January (2.42) where as lowest value was observed at station II (1.75) and during October (2.25). The main causes of the differences occurring in the biodiversity indexes are atmospheric air currents and environmental conditions (Keskin \& Unsal, 1998). The evenness index was found to be highest at station III (0.96) and during the month January (0.95), where as the lowest was found to be at station II (0.90) and during the month October (0.88). The maximum (6.14) Margalef richness value was observed at station III and during the month January (6.32) where as minimum value was observed at station I (3.91) and during the month July (5.82). In diversity index $\left(\mathrm{H}^{\prime}\right)$, Evenness (E) and Mergalef richness (d), there was no significant difference observed. Therefore, it may be concluded that the seasonal difference in species diversity is a common phenomenon in the studied area.

\section{CONCLUSION}

A total of 13 fish species were collected from the different section of Ghodaghodi Lake, belonging to five order, eight family and eleven genera. Fishes were not found uniformly distributed in the lake, it might be due to variation in temperature, depth, transparency, turbidity, conductivity, pH, DO, Free $\mathrm{CO}_{2}$, hardness etc of water. Ghodaghodi Lake is the habitat for different species of fish like Labeo gonius, Mystus tengara, Nandus nandus, Channa striatus, Channa punctatus etc. The dominant order, family and genus of lake were Cypriniformes, Cyprinidae and Labeo gonius respectively. Puntius sophore and Pseudambassis baculis were rare species recorded from the present study where as other species were common. To protect the fish species in Ghodaghodi Lake illegal fishing should be controlled, school based awareness program should be conducted and aquatic animal protection act should be implemented effectively.

\section{REFERENCES}

Anon (2002). Ghodaghodi Lake Complex: Information sheet on Ramsar wetlands (RIS). Submitted to Ramsar Secretariat by Nepal Government.

Day, F. (1878). The fishes of India being a natural history of the fishes known to inhabit the seas and fresh waters of India, Burma and Ceylon. London, Vols. I \& II.

DNPWC and WWF Nepal (2003). Factsheet on Ghodaghodi Lake.

DNPWC and WWF Nepal (2003). Factsheet on Ghodaghodi Lake.

DNPWC (2005). Fact sheets Wetlands of Nepal: Department of National Parks and Wildlife Conservation and WWF Nepal Program, Kathmandu, Nepal.

Edds, D. R. (1986). Fishes of Kali Gandaki/Narayani Rivers, Nepal. Journal of Natural History Museum, Tribhuvan University, Kathmandu, 10 (14): 13-22.

Gubhaju, S. R. (2012). Impact of damming on the environment of flow and persistence of native fishes. In: S.K. Wagle and N. Pradhan (eds) Proceedings of the consultative workshop on fish conservation in Nepal, pp. 79-93.

Gupta, S. P. (1988). Advanced Practical Statistics, Published by S. Chand and Company (pvt.) Ltd. New Delhi.

Gautam, G.; Jain, R.; Poudel, L. and Shrestha, M. (2015). Fish faunal diversity and species richness of tectonic Lake Rupa in the mid- 
hill of central Nepal. International Journal of Fisheries and Aquatic Studies, 2016: 690-694.

IUCN (1998). The Ghodaghodi Tal Conservation Area: A Community Centred Management Plan, IUCN Nepal, Kathmandu, Nepal.

Jayaram K. C. (1981). The Freshwater fishes of India, Pakistan, Bangladesh, Burma and Srilanka- A Handbook. Edited and Published by the Director, Zoological survey of India, Calcutta, India.

Kafle, G. (2006). Status and conservation of Ghodaghodi lake, Kailali, Nepal,Wetland Friends of Nepal.

Kafle, G. (2007). Ghodaghodi Conservation Education Project.

Keskin, C. and Unsal, N. (1998). The Fish Fauna of Go“" kc, eada Island, NE Aegean Sea, Turkey. Italian Journal of Zoology, 65: 299-302.

Lamsal, P.; Pant, K. P.; Kumar, L. and Atreya, K. (2014). Diversity, Uses, and Threats in the Ghodaghodi Lake Complex, a Ramsar Site in Western Lowland Nepal, Research Article of Hindawi Publishing Corporation ISRN Biodiversity Volume 2014, Article ID 680102, 12 pages.

Magurran, A. E. (1988). Ecological Diversity and its Measurement. Princeton University Press, Princeton.

Margalef, R. (1958). Temporal succession and spatial heterogeneity in phytoplankton. In: Buzzati-Traverso (ed), Perspectives in Marine biology, Univ. Calif. Press, Berkeley, pp. 323-347.

Nelson, J. S. (1984). Fishes of the World, WileyInterscience, John Wiley \& Sons, New York, pp. 523.
Pielou, E. C. (1966). The measurement of diversity in different types of biological collections. Journal of Theoretical Biology, 13: 131-144.

Pokharel, K. K. (1999). Fish Bio-diversity of Lakes in Pokhara Valley and need of their Conservation. In Proceeding of IIIrd National Conference on Science and Technology, 1999.

Shannon, C. E. and Wiener, W. (1949). The mathematical theory of communication. Urbana, University of Illinois Press, pp. 177.

Sharma, C. M. and Shrestha, J. (2001). Jour. Environment and Agriculture: Biodiversity, Agriculture and pollution in south Asia, Ecological Society (ECOS), Kathmandu, Nepal, pp. 78-83.

Shrestha, J. (2001). Taxonomic Revision of fishes of Nepal. Jour. Environment and Agriculture: Biodiversity, Agricultural and pollution in South Asia, 2001, Ecological Society (ECOS), Kathmandu, Nepal, pp.171-180.

Shrestha, J. (2003). Gonch- The Fresh Water Shark of Nepal. NAHSON Bulletin 2002-2003, pp. 13-18.

Shrestha, T. K. (2008). Ichthyology of Nepal, Himalayan Ecosphere, Kathmandu Nepal.

Shrivastava , G. (1968). Published book "Fishes of Eastern Uttar Pradesh."

Talwar, P. K. and Jhingram, A. G. (1991). Inland Fishes of India and Adjacent Countries. Volume I and II. Oxford and IBH Publishing Co. India, pp. 1158.

Williamson, M. (1973). Species diversity in ecological communities. In: Bartlett, M.S., Horns, R.W. (eds), The Mathematical Theory of The Dynamics of Biological Populations. Academic, London, pp. 325-336. 